\title{
PENGUATAN PERANAN DAN FUNGSIONAL DARI LEMBAGA APARAT DESA DAN MASYARAKAT DALAM MENJAGA SUMBER DAYA ALAM DI DESA HEGARMANAH
}

\author{
Amelia Cahyadini, Zainal Muttaqin, dan Irvan Duwana \\ Fakultas Hukum Universitas Padjadjaran \\ Email: amelia.cahyadini@unpad.ac.id
}

\begin{abstract}
ABSTRAK. Sumberdaya alam merupakan suatu karunia Tuhan YME yang dapat dimanfaatkan oleh manusia. Seiring perkembangannya, negara Indonesia mengindahkan monopoli pada sumber daya alam di wilayahnya melalui ketentuan UUD 1945 pasal 33 ayat (3). Hak menguasai ini dibagi kembali menjadi antara kewenangan pusat dan kewenangan daerah. Namun dalam prakteknya pembagian kekuasaan atas pengelolaan sumber daya alam kerap menyebabkan masalah tertentu. Di Desa Hegarmanah, yang dikaruniai sumber daya alam berupa air, terjadi singgungan kewenangan antara dua lembaga pemerintah yang memiliki kewenangan mengelola sumberdaya air tersebut. Menanggapi hal ini metode yang digunakan adalah pendidikan masyarakat. MelaluI metode ini penulisakan memberikan advokasi penyegaran keilmuan di bidang hokum kepada aparat Desa Hegarmanah serta sosialisasi regulasi hokum terkait kepada masyarakat, yang bertujuan agar meningkatnya pemahaman hokum aparat desa dan masyarakat, sehingga nantinya dapat diimplementasikan dalam wujud peningkatan kualitas pengelolaan sumberdaya air di Desa Hegarmanah.
\end{abstract}

Kata kunci: Kewenangan; Pengelolaan; Desa; Sumber Daya; Whole of Government.

ABSTRACT. Natural Resources are a gift from God that can be utilized by humans. Along with its development, the Indonesian government allowed the state to monopolize the natural resources which located at its domain, the privilege is refer to the article 33 act 3 The 1945 Constitutions of the Republic of Indonesia. The state is about to divide the monopolize right into two different authority, specifically some part is for the central government and the other is for the local government. This separated conditions of authority practically build some other problem. At the Hegarmanah Village, which blessed by water resources, the problem is come because there is two different government institutions who had the right to administer the resources. From this situation, to respond this problem is by used the villager education method. By this way, authors will provide the advocations which would refresh the law awareness specially for the Hegarmanah's officials, and also give regulation socialization, with the hope for the better law understanding for the officials and the villagers. So in the future, the peoples can implement the knowledge with the Hegarmanah's upgrading quality resources management.

Key words: Authority; Management; Village; Resources; Whole of Government.

\section{PENDAHULUAN}

Bumi dan seisinya merupakan anugerah yang diberikan Tuhan kepada makhluk hidup yang tinggal didalamnya. Bumi diciptakan lengkap dengan fasilitas-fasilitas alami yang dapat dipergunakan oleh manusia, tumbuhan, dan hewan untuk bertahan hidup. Dalam bertahan hidup manusia menggunakan dan mengkonsumsi fasilitas-fasilitas tersebut. Fasilitas tersebut kini biasa disebut sumber daya alam (SDA). Sumber daya alam adalah kesatuan faktor-faktor biologis, fisik, kimia, dan sosial dan membentuk suatu bagian dari lingkungan yang mempunyai nilai guna dan dapat dipergunakan oleh makhluk hidup dalam hal mempertahankan dan memenuhi kebutuhan hidupnya.

Perkembangan SDA masa kini terus dipelajari oleh manusia. Sebagai sector utama pemenuhan kebutuhan hidup manusia, SDA terus dipelajari perkembangannya agar tetap dapat digunakan. Saat ini, SDA dapat digolongkan berdasarkan sifatnya menjadi 3 golongan, yaitu: SDA yang dapat dipulihkan (renewable resources); yang merupakan sumber daya alam yang dapat tetap ada tetapi bergantung kepada pengelolaan dan penggunaannya.
Sumber daya ini contohnya meliputi hutan. Hutan merupakan sebuah sumber dari SDA dimana didalam hutan terkandung SDA yang begitu banyak seperti kayu. Tetapi apabila tidak dikelola dengan baik, dengan terus dieksploitasi, hutan akan kehilangan waktu untuk mengembalikan wujudnya kedalam keadaan seperti awal. Lalu yang kedua merupakan sumber daya alam yang tidak dapat dipulihkan (non renewable resources); yang merupakan SDA yang peersediaannya secara fisik terbatas, seperti batu bara, sehingga perlu rencana pengelolaan yang baik agar sumber daya jenis ini dapat digunakan secara berkelanjutan. Terakhir yaitu continous resources; yaitu sumber daya ini tidak akan habis cadangan persediaannya karena dapat meregenerasi dirinya dalam proses alam, namun kualitasnya terpengaruh oleh tindakan penggunanya, seperti udara dan air.

Indonesia merupakan negara yang memiliki kekayaan sumber daya alam yang melimpah ruah. Hal ini dipengaruhi oleh letak dan kondisi geografis Indonesia itu sendiri, yang dimana Indonesia terletak diantara 2 lempeng samudera dan benua, sehingga merupakan "titik temu" dari karakteristik kedua lempeng benua dan samudera tersebut. Selain itu Indonesia juga merupakan negara yang terdiri 
lebih dari 17.000 gugusan pulau serta kaya akan keberagaman akuatiknya. Dengan segala potensi SDA yang berlimpah ruah ini, Indonesia berusaha menjaga dan menerapkan system pengelolaan SDA dalam aturan tertentu, yang tujuannya untuk mengamanatkan agar potensi sumber daya alam yang dimiliki Indonesia dapat dikuasai secara mandiri untuk kemajuan dan kemakmuran Indonesia.

Potret kekayaan alam Indonesia meliputi bumi, air dan kekayaan alam yang terkandung didalamnya, seperti kekayaan hutan, kebun, laut, pertambangan, minyak dan gas bumi, batu bara, dan banyaklainnya. Dengan banyaknya potensi ini, Indonesia menuangkan kebijakan agar seluruh potensi ini dapat dinikmati, baik secara materi maupun materiil oleh rakyat Indonesia. Salah satu dasar hukum yang paling substansial adalah yang tercantum dalam Pasal 33 ayat (3) Undang-Undang Dasar 1945, yang mengatur bahwa "Bumi, air, dan kekayaan alam yang terkandung di dalamnya dikuasai oleh negara dan dipergunakan sebesar-besarnya untuk kemakmuran rakyat". Berdasarkan ketentuanPasal 33 ayat (3) UUD 1945 ini terdapat unsure penting dalam pengusahaan bumi, air, dan kekayaan alam Indonesia, antara lain adanya unsur: "dikuasai oleh negara" dan "sebesar-besarnya untuk kemakmuran rakyat".

Tercantumnya sumber daya air dalam konstitusi negara Indonesia sebagai salah satu cabang sumber daya alam yang harus mendatangkan manfaat bagi kemakmuran rakyat menjadi salah satu bukti bahwa sektor air merupakan sektor SDA vital dan terpenting, bukanhanya di Indonesia saja tetapi kehidupan manusia secara global. Sumber daya air digunakan masyarakat dalam bertahan hidup dan juga merupakan kunci untuk memenuhi kebutuhan hidup disektor lainnya, semisal petani yang membutuhkan air untuk mengairi sawahnya, dan lainnya. Dengan begitu pentingnya air bagi kehidupan masyarakat, maka dalam hal pengelolaannya butuh proses dan rencana, mengingat air walaupun sebagai continous resources, kualitas air ditentukan oleh pengelolaannya.

Desa Hegarmanah merupakan desa yang terletak di Kecamatan Jatinangor, Kabupaten Sumedang. Desa ini memiliki potensial antara lain galian batu, yang dijadikan mata pencaharian bagi warga sekitar, serta potensi sumber daya air yang berasal dari sungai, yang dijadikan sebagai sector utama untuk menggerakkan perekonomian agraris warga sekitar. Air digunakan untuk pengairan lahan-lahan sawah di desa tersebut. Masyarakat sekitar biasa mengelola sumber air tersebut secara mandiri untuk kebutuhan mereka. Namun, aktivitas masyarakat tersebut kerap kali menimbulkan masalah karena pengelolaan mandiri tersebut kurang tepat sehingga mengakibatkan kerugian untuk masyarakat itu sendiri. Masalah yang paling sering muncul adalah timbulnya kebanjiran di salah satu daerah desa tersebut.

Berdasarkan Undang-Undang no. 6 tahun 2014 tentang Desa, desa adalah kesatuan masyarakat hukum yang memiliki wilayah yang berwenang untuk mengatur dan mengurus urusan pemerintahan. Dalam hal kewenangan, pemerintahan tingkat desa memiliki kewenangan dalam hal pemanfaatan SDA dan lingkungan di daerahnya, sebagai wujud pelaksanaan pembangunan desa, sesuai amanat Pasal 81 ayat (3). Menjadikan pemerintah desa memiliki kewenangan dalam pengelolaan SDA di daerahnya dengan berbasis Badan Usaha Milik Desa (BUM Desa) dalam pengelolaannya, sesuai Pasal 90 huruf c.

Berdasarkan alas an diatas peneliti merasa perlu melakukan advokasi hokum terhadap aparat Desa Hegarmanah serta warga sekitar dalam hal penguatan peranan fungsional aparat desa dalam pengelolaan sumber daya alam yang terdapat di Desa Hegarmanah.

\section{METODE}

Metode pendekatan yang dilakukan oleh penulis dalam PPM ini adalah pendidikan masyarakat. Melalu metode ini penulis akan memberikan advokasi penyegaran keilmuan di bidang hokum kepada aparat Desa Hegarmanah serta sosialisasi regulasi hokum terkait kepada masyarakat, yang bertujuan agar meningkatnya pemahaman hokum aparat desa dan masyarakat, sehingga nantinya dapat diimplementasikan dalam wujud peningkatan kualitas pengelolaan sumber daya air di Desa Hegarmanah.

\section{HASIL DAN PEMBAHASAN}

Desa Hegarmanah merupakan suatu desa yang terletak di Kecamatan Jatinangor, Kabupaten Sumedang, Provinsi Jawa Barat. Desa Hegarmanah muncul sebagai desa pemekaran dari desa Cikeruh yang terletak di kecamatan yang sama. Desa ini muncul dan disahkan sebagai desa melalui Surat Keputusan (SK) Bupati Sumedang no. 140/SK.19 Pem/1983 yang dikeluarkan pada tanggal 22 Januari 1983, yang menyebutkan perihal pemekaran dan pemisahan daerah antara Desa Cikeruh dan Desa Hegarmanah. Dahulu, sebagian wilayah Desa Hegarmanah merupakan lahan tidur eksperkebunan karet, yang seiring perkembangannya, pemanfaatan lahan desa berubah sejak tahun 1988 dimana Universitas Padjadjaran menjadikan kawasan desa sebagai wilayah pendidikan tinggi. Secara geografis, desa ini berbatasan dengan 4 desa pada arah mataangin 
yang berbeda, sebelah utara desa berbatasan dengan Desa Cileles, selatan dengan Desa Jatimukti, timur dengan Desa Cinanjung (Kecamatan Tanjungsari) dan di barat berbatasan dengan Desa Cikeruh.

Desa Hegarmanah memilikiluas 331 Hektar (Ha) secara keseluruhan, yang terbagi menjadi perumahan, sawah, ladang, pemakaman, lapangan, dan perkantoran. Secara historis desa ini memiliki potensi sumber daya perkebunan dan pertanian yang lebih luas, akan tetapi perubahan fungsi dan tata guna tanah secara bertahap mulai berlaku dan khususnya berdampak pada wilayah desa. Berdasarkan SK Gubernur Kepala DT I Jabar no. 583/SK-PIL/1989, Kecamatan Jatinangor ditetapkan sebagai kawasan pendidikan tinggi provinsi Jawa Barat. Penetapan Kawasan Pendidikan Tinggi (PKT) ini telah mengubah wilayah Jatinangor yang dahulu didominasi oleh perkebunan dan pertanian, terutama perkebunan karet menjadi kawasan yang dipenuhi gedung-gedung perkuliahan beserta mahasiswa didalamnya. Terhitung terdapat 5 perguruan tinggi yang membangun dinastinya di kecamatan ini, yaitu Institut Manajemen Koperasi Indonesia (IKOPIN) pada tahun 1982, Universitas Padjadjaran (UNPAD), sejak tahun 1982, Institut Pemerintahan Dalam Negeri (IPDN) pada tahun 1989, Universitas Winaya Mukti (UNWIM) pada tahun 1991, dan Institut Teknologi Bandung (ITB).

Perubahan fungsi wilayah ini secara khusus berpengaruh terhadap kondisi Desa Hegarmanah. Menurut keterangan, Desa Hegarmanah dahulu memiliki luas wilayah dengan dominasi perkebunan karet.SejakUNPADmasukdanmenetapdiJatinangor, sebagian wilayah desa dialihfungsikan menjadi wilayah perguruan tinggi UNPAD, khususnya Fakultas Pertanian dan Fakultas Peternakan. Perubahan fungsional wilayah ini membawa dampak positif dan negative terhadap desa. Dengan adanya kebijakan menjadikan Jatinangor sebagai wilayah perguruan tinggi tentu akan membawa keuntungan bagi warga sekitar. Contohnya dari segi ekonomi, pelaku usaha mikro, kecil dan menengah akan dapat menaikkan pendapatan usahanya karena dipengaruhi oleh factor pendatang yang masukke wilayah Jatinangor, yang mana dalamkonteks PKT, mayoritas penduduk luar yang menetap di Jatinangor adalah mahasiswa. Tercatat, terdapat lebih dari 30-35 ribu mahasiswa dari kelima perguruan tinggi yang ada di Jatinangor yang tinggal dan menetap selama masa studi berlangsung. Dimana dapat diperkirakan dalam satu hari, perputaran uang di daerah ini mencapai sekitar 45 miliar. Tentunya menjadi angin segar bagi pelaku usaha untuk memulai atau mengembangkan usahanya di daerah ini. Namun, dampak negatif pun tidak dapat dihindari, berkaitan dengan alih fungsi wilayah, telah menyebabkan fungsi penyerapan air di daerah desa menurun. Kemerosotan luas perkebunan yang tersiasati tidak diimbangi dengan pembangunan gedung akademik maupun hunian, telah menyebabkan fungsi resapan tanah di desa berkurang. Berdasarkan keterangan, pada wilayah Desa Hegarmanah kerap kali terjadi banjir ketika musim hujan. Banjir yang terjadi memiliki factor utama penyebabya itu fungsi resapan yang berkurang. Selain itu, kenaikan jumlah penduduk menyebabkan volume sampah rumah tangga yang dihasilkan per harinya melonjak, sehingga banyak sampah yang menutup saluran air yang akhirnya membuat saluran air tersebut meluap ketika hujan datang.

Desa Hegarmanah dianugerahi 2 sumber mata air, yang masing-masing terletak di RW 07 Desa Hegarmanah (dibawah jembatan cincin), dan di sekitar perbatasan dengan Kecamatan Tanjungsari. Potensi sumber daya air ini berupa 1 mata air berukuran kecil dan juga 1 anak sungai Cikeruh. Kedua sumber air di desa ini diperuntukkan bagi kepentingan masyarakat sekitar. Disebutkan dalam keterangan, bahwasanya daerah Hegarmanah dahulu memiliki lebih banyaksumber air, yang mana mencukupi untuk kebutuhan air warga desa, baik untuk konsumsi rumah tangga maupun untuk irigasi lahan pertanian, namun seiring pertumbuhan daerah yang terusmaju, sumber-sumber air yang dahulu ada kini sedikit demi sedikit menghilang. Hal ini tidak lepas dari pengaruh pembangunan yang menyebabkan turunnya kemampuan tanah sekitar untuk menyerap air, sehingga air tanah lama kelamaan kering. Dengan kedua sumberdaya air yang tersisa, keduanya dipergunakan desa dalam pemenuhan kebutuhan masyarakat sehari-hari serta untuk irigasi lahan pertanian. Tidak cukup sampai situ, sumber air pun dibagi untuk keperluan industry pabrik sekitar. Khusus sector rumah tangga, untuk memenuhi kebutuhan air masyarakat, pemerintah desa Hegarmanah bekerjasama dalam hal menyalurkan air dari sumber lain, yaitu mata air yang terletak di Desa Cileles, yang terletak di bagian utara Desa Hegarmanah. Hal ini dilakukan pemerintah desa setempat karena volume debit air sumber daya air desa dirasa tidak cukup mumpuni untuk memenuhi kebutuhan air masyarakat. Penarikan air ini dilakukan oleh aparat desa melalui pipa.

Salah satu anak sungai yang menjadi sumber air di Desa Hegarmanah adalah Sungai Cikeruh. Sungai ini merupakan anak sungai dari sungai Citarum yang melintas dari Desa Cileles. Desa Hegarmanah hanya memiliki sumber air dari anak sungai Cikeruh. Dalam pemanfaatannya, pemerintah desa membagi arus sungai menjadi 2. Namun pengelolaan sumberdaya air dari anak sungai Cikeruh pun tidak dapat difokuskan untuk kebutuhan warga. Hal ini dikarenakan sumber daya air berupa sungai yang ada 
dibagi lagi dengan kebutuhan industry sekitar. PT KAHATEX (Kahatex) merupakan industry tekstil yang bertempat di Jalan Raya Rancaekek. Dalam kegiatanin dustrinya, Kahatex menggunakan sumber daya air yang berasal dari Desa Hegarmanah. Proses pembagian air ini melalui katup, dimana pengelolaan pembagian air dilakukan oleh suatu lembaga bentukan pemerintah desa bernama Perkumpulan Petani Pemakai Air (P3A) Desa Hegarmanah.

Perencanaan pengelolaan air secara mandiri merupakan mimpi dari pemerintah desa dalam hal pelayanan hajat hidup masyarakat desa setempat. Program pengelolaan air secara mandiri di desa ini bernama Penyediaan Air Minum dan Sanitasi Berbasis Masyarakat (PAMSIMAS). Melalui program ini, sumber-sumber air yang ada di dalam desa akan dialokasikan seluruhnya untuk kebutuhan masyarakat. Sayangnya, program ini baru akan dilaksanakan secara serentak (nasional) pada tahun 2019.

Amanat luhurdalam UUD 1945, pasal 33 ayat (3) secara tegas menyebutkan bahwa: "Bumi, air dan kekayaan alam yang terkandung didalamnya, dikuasai negara dan dipergunakan sebesar-besarnya bagi kemakmuran rakyat secara adil dan merata." Pasal ini menempatkan negara pada fungsi penyelenggaraan, dimana hal ini berupa "monopoli" yang dikuasakan oleh undang-undang kepada pemerintah demi kemakmuran rakyat. Hal ini diperjelas melalui Undang-Undang no. 7 tahun 2004 tentang Sumber Daya Air, disebutkan bahwa sumberdaya air merupakan karunia Tuhan Yang Maha Esa, yang memberikan manfaat serba guna untuk mewujudkan kesejahteraan bagi seluruh rakyat di segala bidang, baik sosial, ekonomi, budaya, politik maupun ketahanan nasional. Kewenangan negara dalam hal ini merupakan marwah konstitusional yang harus diselenggarakan dengan dimaksudkan untuk sebesarbesarnya kemakmuran rakyat. Namun, kenyataan yang terjadi di lapangan terutama pada wilayah sungai di Desa Hegarmanah tidaklah demikian. Dimensi kewenangan antara instansi Balai Besar Wilayah Citarum dan Pemerintah Desa Hegarmanah yang besar, justru bukan memupuk kepedulian besar terhadap pengelolaan sungai.

Berdasarkan keterangan dan kondisi geografis sumberdaya air yang berada di desa, anak sungai Cikeruh bersumber dari mata air sungai Cikeruh dan sungai Cikeruh itu sendiri berasal darihulu sungai Citarum, yang berarti sungai Cikeruh merupakan anak sungai Citarum. Rencana pengelolaan sumber daya air berupa sungai diatur dalam Peraturan Pemerintah (PP) no. 35 tahun 1991 tentang Sungai. Dalam pasal 1 ayat (1) PP no. 35 tahun 1991, disebutkan bahwa sungai adalah tempat-tempat dan wadah-wadah serta jaringan pengaliran air mulai dari mata air sampai muara dengan dibatasi kanan dan kirinya serta sepanjang pengalirannya oleh garis sempadan. Sungai Citarum itu sendiri merupakan sungai yang termasuk dalam wilayah sungai strategis nasional dengan kode wilayah: 02.06.A3 berdasarkanPeraturan Menteri (PERMEN) PekerjaanUmum dan Perumahan Rakyat no. 04/ PRT/M/2015 yang panjangnya melintas di 10 Kabupaten dan 2 Kota, yang pada wilayah-wilayah tersebut sungai Citarum menjadi sungai utama.

Berdasarkan Peraturan Menteri (PERMEN) Pekerjaan Umum dan Perumahan Rakyat no. 34/ PRT/M/2015, Balai Besar Wilayah Sungai Citarum (BBWS Citarum) memiliki tugas perihal pengelolaan sumber daya air di wilayah sungai Citarum yang meliputi:

1. Perencanaan

2. Pelaksanaan Konstruksi

3. Operasi dan Pemeliharaan dalam rangka Konservasi dan Pendayagunaan sumber daya air dan pengendalian daya rusak air pada sungai, danau, waduk, bendungan dan tampungan air lainnya, irigasi, air tanah, air baku, rawa, tambak dan pantai.

Serta fungsi yang meliputi:

1. Penyusunan pola dan rencana pengelolaan sumber daya air pada wilayah sungai;

2. Penyusunan rencana dan program, studi kelayakan dan perencanaan teknis/desain/ pengembangan sumber daya air;

3. persiapan, penyusunan rencana dan dokumen pengadaan barang dan jasa;

4. pelaksanaan pengadaan barang dan jasa serta penetapan pemenang selaku Unit Layanan Pengadaan (ULP);

5. pengendalian dan pengawasan konstruksi pelaksanaan pembangunan sumber daya air;

6. penyusunan rencana dan pelaksanaan pengelolaan kawasan lindung sumber air pada wilayah sungai;

7. pengelolaan sumberdaya air yang meliputi konservasi dan pendayagunaan sumberdaya air serta pengendalian daya rusak air pada wilayah sungai;

8. pengelolaan sistem hidrologi;

9. pengelolaan system informasi sumber daya air;

10. pelaksanaanoperasi dan pemeliharaan sumber daya air pada wilayah sungai;

11. pelaksanaan bimbingan teknis pengelolaan sumber daya air yang menjadi kewenangan provinsi dan kabupaten/kota;

12. penyiapan rekomendasi teknis dalam pemberian ijin atas penyediaan, peruntukan, penggunaan dan

13. pengusahaan sumber daya air pada wilayah sungai; 
14. fasilitasi kegiatan Tim Koordinasi Pengelolaan SumberDaya Air pada wilayah sungai;

15. pemberdayaan masyarakat dalam pengelolaan sumber daya air;

16. pelaksanaan penyusunan laporan akuntansi keuangan dan akuntansi barang milik negara selaku Unit Akuntansi Wilayah;

17. pelaksanaan pemungutan, penerimaan dan penggunaan biaya jasa pengelolaan sumber daya air (BJPSDA) sesuai dengan ketentuan peraturan perundang-undangan; dan

18. pelaksanaan urusan tata usaha dan rumah tangga balai serta koordinasi dengan instansi terkait.

Selain aturan yang mengikat BBWS Citarum berdasarkan sumber dan kondisi geografis dari sungai terkait, berdasarkan kewenangannya pemerintah desa pun memiliki kewenangan dalam mengelola sumber daya air di wilayahnya. Melalui UU no. 6 tahun 2014 tentang Desa, pasal 60 huruf c, desa wajib memprioritaskan BUM Desa dalam pengelolaan sumber daya alam di Desa. Setidaknya inilah yang telah dijalankan oleh BUM Desa Hegarmanah, melalui surat keputusan resmi yang dikeluarkan desa, aparat desa hegarmanah menciptakan suatu organisasi pengelola air yaitu Pemberdayaan Perkumpulan Petani Pemakai Air (P3A) atau yang kerap disebut Gabungan Kelompok Tani (Gapoktan) atau mitracai. Dalam hal ini BUM Desa berfungsi sebagai pengawas dan penyalur dana kepada P3A untuk beroperasi, yang mana P3A bertugas membuka dan menutup katup air yang berada di bawah jembatan cincin dengan sesuai kebutuhan. Selain dari BUM Desa, P3A memiliki sumber dana mandiri yang berasal dari potongan hasil panen untuk mengisi kas. Sayangnya terhadap masalah-masalah pengelolaan air di desa ini, aparat desa cenderung menyerahkan kewenangan berkaitan dengan masalah pengelolaan pada BBWS, disbanding bekerja sama dalam menyelesaikan masalah ini.

Fakta ini menunjukkan bahwa antara koordinasi lembaga khususnya dalam pengelolaan sumber daya sungai di Desa Hegarmanah masih lemah. Dimensi kewenangan yang besar antara kedua instansi diatas tidak menjadi pemicu keduanya mampu bekerja sama secara baik dalam hal pelayanan publik. Tanggung jawab merupakan suatu ukuran yang menunjukkan seberapa jauh sebuah proses dilakukan dengan tetap berada dalam koridor kewenangannya masing-masing.

Dalam hokum administrasi dikenal istilah Whole of Government (WoG), yaitu sebuah pendekatan penyelenggaraan pemerintahan yang menyatukan upaya-upaya yang berlandaskan asas gotong-royong, sehingga konsep pelayanan yang dihasilkan mengandung mengandung prinsip kolaboratif, yang mana dalam lingkup koordinasi yang lebih fleksibel, akhirnya akan membuat suatu penyelenggaraan pelayanan public akan kembali pada hakikatnya yaitu pada kemaslahatan masyarakat. Pendekatan $W o G$ telah lama berkembang, khususnya pada negaranegara maju yang menganut system hokum anglosaxon, seperti Inggris, Australia, dan Selandia Baru. Konsep segar $W o G$ mengemukakan konsep integrasi baru antar instansi pemerintahan, misalnya di Australia, melalui integrasi kewenangan, pemerintah Australia dapat focus melakukan pendekatan pada kebijakan, yang berdampak pada pembangunan dan penyelenggaraan layanan publik. Di beberapa negara, $W o G$ dipandang sebagai bagian dari respon terhadap ilusi New Public Management (NPM) yang banyak menekankan penyelenggaraan publik pada aspek efisiensi dan mendorong ego sectoral disbanding perspektif integrasi sektor. $W o G$ mengenalkan suatu system bagaimana caranya sebuah instansi pelayanan public bekerja lintas batas dan sector guna mencapai tujuan rakyat sebagai respon terpadu pemerintah, melalui aspek gotong-royong yang menghilangkan sekat sektoral antar lembaga.

Melalui pemahaman mendalam yang diejawantahkan melalui kegiatan sosialisasi dan advokasi hokum mengenai pendekatan $W o G$ ini, diharapkan kedepannya Indonesia dapat meninggalkan system uzur yang kaku pada aturan, dimana system ini pada awalnya memang baik demi menunjang kepastian hukum, tetapi dalam perkembangannya, justru berkebalikan karena ditelan ego sektora lantar lembaga, sebagaimana yang terjadi pada instansi yang berwenang mengelola sungai di Desa Hegarmanah. Justru dengan dimensi kewenangan yang serupa, disitu konsep $W o G$ dapat masuk dan memperbaiki sistem yang ada.

\section{SIMPULAN}

Desa adalah kesatuan masyarakat hukum yang memiliki wilayah yang berwenang untuk mengatur dan mengurus urusan pemerintahan. Dalam hal kewenangan, pemerintahan tingkat desa memiliki kewenangan dalam hal pemanfaatan SDA dan lingkungan di daerahnya, sebagai wujud pelaksanaan pembangunan desa, sesuaiamanat Pasal 81 ayat (3). Menjadikan pemerintah desa memiliki kewenangan dalam pengelolaan SDA di daerahnya dengan berbasis Badan Usaha Milik Desa (BUM Desa) dalam pengelolaannya, sesuai Pasal 90 huruf c.

Berkaitan dengan sumber daya alam, Desa Hegarmanah dianugerahi 2 sumber mata air, yang masing-masing terletak di RW 07 Desa Hegarmanah (dibawah jembatan cincin), dan di sekitar perbatasan dengan Kecamatan Tanjungsari. Potensi sumber daya air ini berupa 1 mata air berukuran kecil dan 
juga 1 anak sungai Cikeruh. Kedua sumber air di desa ini diperuntukkan bagi kepentingan masyarakat sekitar. Sayangnya akibat perkembangan masa, wilayah sungai daerah Desa Hegarmanah kerap kali dirundung masalah misalnya banjir saat musim hujan ataupun kekeringan ketika sumber air harus dibagi-bagi dan tidak difokuskan untuk kebutuhan warga. Yang kembali disayangkan, pihak-pihak yang berwenang dalam pengelolaan air ini, dilihat dari sumber mata airnya terdapat lembaga bernama Balai Besar Wilayah Citarum dan juga perangkat desa melalui BUM Desa, saling menyalahkan akibat masalah-masalah ini, karena keduanya menganggap kewenangan pengelolaan air dimiliki dan menjadi tanggungjawab masing-masing dari mereka. Ini dapat terjadi karena dimensi kewenangan pengelolaan air sangat besar antar keduanya.

Dari sudut pandang hokum administrasi negara dikenal suatu pendekatan bernama Whole of Government, dimana pada pendekatan ini diutamakan tujuan penyelenggaraan public melalui integrasi antar lembaga sehingga dapat terfokus pada tujuan kemaslahatan masyarakat. Pendekatan ini perlu disosialisasikan dalam system pemerintahan Indonesia, secara mendetil, karena mungkin saja masalah-masalah seperti ini bukanhanya terjadi di Desa Hegarmanah, namun di daerah-daerah lain yang aparat pemerintahnya memiliki pemahaman yang kurang mendalam terhadap hukum.

\section{DAFTAR PUSTAKA}

Utomo, Tri Widodo W, 2006, Pola Pengelolaan Sumber Daya dan Lingkungan Berbasis Pengetahuan dan Kearifan Lokal (Local Wisdom) di Kalimantan, Samarinda, Pusat Kajian dan Pendidikan dan Pelatihan Aparatur III (PKP2A III) LAN.
Hidayat, Pengelolaan Sumber Daya Alam Berbasis Kelembagaan Lokal, Jurnal Sejarah CITRA LEKHA, Vol. XV, Medan: Februari 2011.

Irianto, Gatot, 2006, Pengelolaan Sumber daya Lahan dan Air: Strategi Pendekatan dan Pendayagunaannya, Jakarta, Papas Sinar Sinanti.

Yunita, Desi, dan Achadiyani. 2018. Penguatan Lembaga Pengelola Air di RW 11 Desa Cilayung Kecamatan Jatinangor Kabupaten Sumedang, Jurnal Dharmakarya, Vol. 7 no. 1.

Perwira, Indra, 2011, Hubungan Pusat dan Daerah dalam Pengelolaan Sumber Daya Alam, Disampaikan dalam Seminar Nasional Pola Hubungan Kewenangan Pusat dan Daerah, Kerjasama FH Unpad dan Dewan Perwakilan Daerah.

Suwarno, Yogi, dan Sejati, Tri Atmojo, 2017, Modul Pelatihan Dasar Calon PNS: Whole of Government, Jakarta, LAN.

Shergold, P., \& others, 2004, Connecting government: Whole of government responses to Australia "s priority challenges, Launching speech made on 20 April 2004, Canberra Bulletin of Public Administration, (112), 11.

Undang-Undang Dasar Republik Indonesia tahun 1945

Undang-Undang no. 7 tahun 2004 tentang Sumber Daya Air

Undang-Undang no. 6 tahun 2014 tentang Desa

Peraturan Pemerintah no. 35 tahun 1991 tentang Sungai

Peraturan Menteri Pekerjaan Umum dan Perumahan Rakyat No. 04/PRT/M/2015 